\title{
NOTES OF LOPHOZIA. VII. ON THE DISTRIBUTION OF SOME SPECIES OF LOPHOZIA IN GEORGIA (CAUCASUS)
}

\section{ЗАМЕТКИ ПО РОДУ LOPHOZIA. VII. О РАСПРОСТРАНЕНИИ НЕКОТОРЫХ ВИДОВ LOPHOZIA В ГРУЗИИ (КАВКАЗ)}

\author{
VADIM A. BAKALIN ${ }^{1,2} \&$ KETEVAN TIGISHVILI $^{3}$ \\ ВАДИМ А. БАКАЛИН ${ }^{1,2}$, КЕТЕВАН ТИГИШВИЛИ ${ }^{3}$
}

Abstract

\begin{abstract}
Revision of the liverwort collection in Tbilisi Institute of Botany (TBI) has revealed four Lophozia taxa new for the liverwort flora of Georgia : L. lantratoviae Bakalin, L. longidens (Lindb.) Macoun, $L$. perssonii $\mathrm{H}$. Buch et S.W. Arnell and $L$. wenzelii (Nees) Steph. var. massularioides Bakalin. A comment on these new findings is supplemented by the list of all Lophozia specimens in TBI.
\end{abstract}

Резюме

При ревизии коллекции печеночников, хранящейся в Тбилисском институте ботаники (TBI), обнаружено 4 новых для Грузии таксона Lophozia: L. lantratoviae Bakalin, L. longidens (Lindb.) Macoun, L. perssonii H. Buch et S.W. Arnell и L. wenzelii (Nees) Steph. var. massularioides Bakalin. Приводится описание этих новых находок и список всех видов Lophozia с территории Грузии, образцы которых хранятся в ТВI.

KEYWORDS: Lophozia, liverworts, Hepaticae, Georgia, Caucasus.

The last checklist of Georgian bryophytes was published at 2004 (Chikovani \& Svanidze, 2004). It includes data on distribution of 174 taxa of hepatics (3 hornworts and 171 liverworts) within administrative subunits and represents a shortened version of conspectus published 18 years before (Chikovani, 1986). Nomenclature usage in both papers is quite confusing. For Lophozia, Chikovani lists 6 species (if we omit species referred now to other genera): 1) Lophozia alpestris Schleich., which most likely means L. sudetica, since "Lophozia alpestris", in its correct sense, is a member of Leiocolea and is cited in the paper under Leiocolea collaris (Nees) Schljak., 2) Lophozia ascendens (Warnst.) R.M. Schust., 3) L. excisa (Dicks) Dumort., 4) L. porphyroleuca (Nees) Schiffn., which apparently means L. guttulata (Lindb. et Arnell) A. Evans, but not L. silvicola H. Buch (as it was shown by R.N. Schljakov (1981), L. porphyroleuca is synonymous with $L$. ventricosa, which Schljakov treated in the sense of L. silvicola $\mathrm{H}$. Buch), 5) L. ventricosa (Dicks.) Dumort., 6) L. wenzelii (Nees.) Steph.

In the course of the recent achievements of molecular phylogenetics, the aforementioned more or less narrow generic concept of Lophozia became even narrower after segregating Lophoziopsis Konstant. et Vilnet, with $L$. excisa (Dicks.) Konstant. et Vilnet (=Lophozia excisa) and Pseudolophozia Konstant. et Vilnet (with P. sudeti- ca (Nees ex Hueb.) Konstant. et Vilnet (= Lophozia sudetica)) (Konstantinova \& Vilnet, 2009). These "supersplitted" genera, however, are not distinct in morphology, so we retain Lophozia in the sense of Schljakov's (1980) Lophozia or Lophozia subg. Lophozia sensu Schuster (1969). This morphologically natural group is characterized by a combination of features (present in the most phases of constituent taxa) such as presence of microcellous layer in the ventral portion of the stem, angular gemmae and bilobate leaves sheathing the stem in the base.

Revision of Lophozia specimens in TBI allowed the first author to reveal new species to Georgia, as well as to clarify distribution of some other taxa. All cited specimens examined are from TBI with some duplicates in VBGI.

\section{1) Lophozia lantratoviae Bakalin}

The species was described relatively recently (Bakalin, 2003), and its distribution is still imperfectly known. The original collection of the species is from southern part of the Republic of Yakutia (East Siberia), and first it was regarded (1.c.) as a probable East Siberian endemic taxon. Afterwards it was recorded from other regions of Siberia, as well as in the Russian Far East and in Russian part of the Caucasus (Konstantinova et al., 2009). Recently it was also recorded for Seorak Mt. in northern

1 - Botanical Garden-Institute FEB RAS, Makovskogo Street, 142, Vladivostok, 690024, Russia - Россия 690024 Владивосток, ул. Маковского, 142, Ботанический сад-институт ДВО РАН

2 - Institute of Biology and Soil Science FEB RAS, Stoletiya Vladivostoka Avenue 159, Vladivostok, 690022, Russia - Poccия 690022 Владивосток, пр. Столетия Владивостока, 159, Биолого-почвенный институт ДВО РАН; e-mail: v bak@list.ru

3 - Institute of Botany of Ilia State University, Botanikuri Street 1, Tbilisi, 0105, Georgia; e-mail: ketevan.tigishvili@gmail.com 

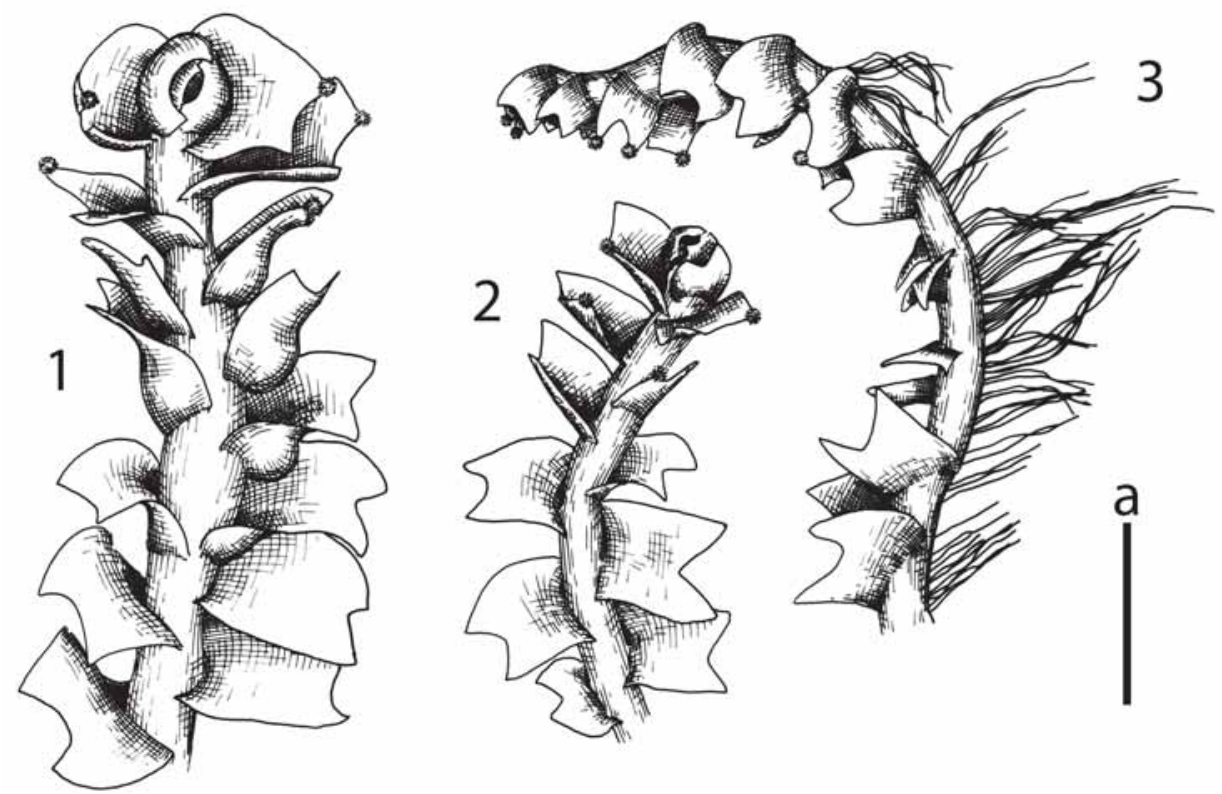

Fig. 1. Lophozia lantratoviae Bakalin. 1 - male branch, dorsal view; 2 - sterile branch, dorsal view; 3 - sterile branch, lateral view. Scale: $\mathrm{a}-1 \mathrm{~mm}$, for 1-3. All from N. Chikovani, leg. 14.VII.1976 (TBI).

part of South Korea (Choi et al., 2012). Taking into account presently known distribution patterns of L. lantratoviae, its area may be regarded as Temperate - South Boreal Montane Asian. L. lantratoviae commonly occurs on stones along streams in spruce and fir forests in the middle mountain belt. Only one noticeable exception is in Kamchatka Peninsula, where the species grows in the mountain tundra belt on wet fine ground along temporary stream (Bakalin, 2009).

The diagnostic feature of the species is the combination of biconcentric oil-bodies and brown gemmae. A complex of differentiating features from morphologically related taxa, as well as illustrations were published by Bakalin (2003, 2005). Since the species was illustrated only for Yakutia specimens, we provide here figures based on material from Georgia (Fig. 1.).

Specimens examined: Georgia. Khevi, Kazbegi, Devdoraki Canyon, $1900 \mathrm{~m}$ alt., cliffs. 14.VII.1976. N. Chikovani, two specimens from one locality (was identified as L. wenzelii).

2) Lophozia perssonii H. Buch et S.W. Arnell

The species occurs sporadically across northern Eurasia, being noticeably rare in Northern America (Bakalin, 2011). Throughout its range, this species is restricted to limestone areas, but surprisingly it has never been recorded in the Caucasus. We found one specimen from Svaneti, the area rich in calcareous rocks. The species is characterized by a combination of brown to almost orange-red gemmae with long persistent one or two large oil-bodies and whitish plant color. Before the specimen was identified as "L. alpestris" from which it can be easily distinguished by aforementioned features. The differentiation of $L$. perssonii from other morphologically related taxa is discussed by Schljakov (1980) and Bakalin (2005). During the recent molecular works it was found that this taxon has molecularly nothing to do with other
Lophozia (Söderström et al., 2010) and L. perssonii was segregated to the genus Oleolophozia L. Söderstr., De Roo \& Hedd. Unfortunately, this point of view can hardly be supported by morphology; for this reason we are following Bakalin (2011) and retain the species within Lophozia.

Specimen examined: Georgia. Svaneti, Lendzheri Village area, limestone cliffs. 3.VII.1975 (no data on collector name)

3) Lophozia wenzelii (Nees) Steph. var. massularioides Bakalin

This relatively recently described variety (Bakalin, 2005 ) with high probability belongs to the group of Caucasian neo-endemics. In the typical phase it is easily recognized by yellow color, large size, and chaotic distribution of fungal hyphae in the stem. In the course of more detailed studies, however, some transitional forms to var. wenzelii were found. Formerly, this species was recorded only in Rhododendron caucasicum communities. Our record attributes it to a different community formed by Juniperus, which may be similar in climatic under-canopy conditions. We found only one specimen in the herbarium TBI, but we are certain this species will be found in many other localities in the course of further studies of hepatics in Georgia.

Specimen examined: Georgia. Shivsheti Range, $2200 \mathrm{~m}$ alt., subalpine belt, on soil under juniper branches. 20.VIII.1971. N. Chikovani (was identified as L. wenzelii s.1.)

4) Lophozia longidens (Lindb.) Macoun

This species with rather distinct appearance has never been recorded for Georgia. We were able to find it in a previously unpublished collection from Lagodekhi Strict Nature Reserve.

Specimen examined: Georgia. Kakheti, Lagodekhi Strict Nature Reserve, subalpine belt, decaying wood. 3.IX.1984. K. Tigishvili. 
Rather numerous re-identifications indicate the need of total revision of Lophozia in Georgia. For example, $L$. sudetica (as "L. alpestris") in Georgia was treated as a common taxon, distributed in all Georgian administrative subunits (Chikovani \& Svanidze, 2004), but we have found only three specimens in the TBI (all from Kakheti), while others were re-identified as L. excisa and L. ventrcosa. A total revision of Georgian Lophosia herbarium collections may help to better understand the distribution patterns of Lophozia within the country. Thus, we provide the catalogue of the TBI specimens of Lophozia (with the exception of the above mentioned species), the names under which the specimens were kept before are in parentheses.

Lophozia excisa (Dicks.) Dumort. - Mtiuleti, Aragvi River Canyon, $2780 \mathrm{~m}$ alt., alpine meadow. 06.VIII.1971. K. Kimeridze ("L. alpestris").

Lophozia guttulata (Lindb. et Arnell) A. Evans - Trialeti, Bakuriani, 05.VII.1967. N. Chikovani (L. porphyroleuca); Sakachavo, 18.VI.1916. Ya. Lepchenko (L. porphyroleuca); Utseri 05.VII.1877 V. Brotherus (L. porphyroleuca); Adjara, iter Otingo 30.VIII.1910. G. Woronow (L. ventricosa s.1.).

Lophozia sudetica (Nees ex Hueb.) Grolle - Kakheti, Lagodekhi Strict Nature Reserve, $2100 \mathrm{~m}$ alt., NW-facing slope in Carpinus forest, on cliff. 29.VIII.1984. K. Tigishvili, two specimens from one locality (Lophozia sp., Leiocolea badensis (Gott.) Jørg.); $2150 \mathrm{~m}$ alt., NW-facing slope in Carpinus forest, on cliff. 28.VIII.1984. K. Tigishvili (Lophozia $\mathrm{sp.).}$

Lophozia ventricosa (Dicks.) Dumort. var. ventricosa Mtiuleti, Dusheti District, 1730 m alt., Logoksa Mt., alpine meadow, on soil. 05.VIII.1971. N. Chikovani (" $L$. alpestris"); Adjara, $1600 \mathrm{~m}$ alt., on soil. 17.VIII.1971. N. Chikovani (L. porphyroleuca), Shavsheti range, $2300 \mathrm{~m}$ alt. 20.VIII.1971 N. Chikovani (L. ventricosa s.1.); Aragvi River Basin, Mleti Village area, $2500 \mathrm{~m}$ alt., big boulders. 05.VIII.1971. G. Zamtaradze (“L. alpestris"), Kurkuta Mt., $2400 \mathrm{~m}$ alt., Rhododendron thickets. 19.VIII.1971. K. Kimeridze (L. ventricosa s.1.), $2400 \mathrm{~m}$ alt. 19.VIII.1971 Kimeridze (L. ventricosa s.1.); Meskheti, Alkhatsikhi District, Goderdzi Pass, on rotten wood. 15.VII.1968 I. Dylevskaya (“L. incisa (Schrad.) Dumort.”).

\section{ACKNOWLEDGEMENTS}

We cordially thank cryptogamic herbarium curator of TBI Ms. N.G. Dekanoidze for providing the Lophozia collection at our disposal. The work of V.A. Bakalin was partially supported by the Russian Foundation for Basic Research, grants No. 13-04-00775, 12-04-91150.

\section{LITERATURE CITED}

BAKALIN, V.A. 2003. Notes on Lophozia IV. Some new taxa of Lophozia sensu stricto. - Ann. Bot. Fennici 40: 47-52.

[BAKALIN, V.A.] БАКАЛИН В.А. 2005. Монографическая обработка рода Lophozia (Dumort.) Dumort. s. str. - [The monograph of the Lophozia (Dumort.) Dumort. s. str.] M., Наука. [Moscow, Nauka] 238 $p p$.

[BAKALIN, V.A.] БАКАЛИН В.А. 2009. Флора и фитогеография печеночников (Marchantiophyta, Anthocerotophyta) Камчатки и прилегающих островов. - [Hepatics (Marchantiophyta, Anthoceratophyta) flora and phytogeography of Kamchatka and adjacent islands.] M., Изд-во КMК. [Moscow, KMK Scientific Press] 367 pp.

BAKALIN, V.A. 2011. Notes on Lophozia VI. Taxonomy and distribution of Lophozia and Schistochilopsis (Lophoziaceae) in North America north of Mexico. - Bryologist 114(2): 298-315.

[CHIKOVANI, N.V.] ЧИКОВАНИ, Н.В. 1986. Bryophyta. Флора споровых растений Грузии. Тбилиси, Мецниереба [Flora of sporebearing plants of Georgia. Tbilisi, Metsniereba]: 786-851.

CHIKOVANI, N. \& T. SVANIDZE 2004. Checklist of bryophyte species of Georgia. - Braun-Blanquetia 34: 97-116.

CHOI, S.S., V.A. BAKALIN, C.H. KIM \& B.Y. SUN 2012. Unrecorded liverwort species from Korean bryoflora. - Korean J. Plant Taxonomy 42(1): 80-90.

[KONSTANTINOVA, N.A. \& O.V. LAVRINENKO] КOНCTAHTИНОВА Н.А., О.В. ЛАВРИНЕНКО 2002. К флоре Hераticae Ненецкого автономного округа (северо-восток европейской части России). - [On flora of Hepaticae of the Nenets Autonomous Area (Arkhangelsk Region, north-eastern European Russia).] Бот. журн. [Bot. Zhurn.] 87(9): 43-49.

KONSTANTINOVA, N.A. \& A.A. VILNET 2009. New taxa and new combinations in Jungermanniacles (Hepaticae). - Arctoa 18: 65-67.

[SCHLJAKOV, R.N.] ШЛЯКОВ P.H. 1981. Lophozia longiflora (Hepaticae) - частый компонент растительных сообществ. - [Lophozia longiflora (Hepaticae) - a frequent component of plant communities.] Бот. журн. [Bot. Zhurn.] 66(8): 1197-1205.

SCHUSTER, R.M. 1969. The Hepaticae and Anthocerotae of North America. Volume II. - New York, Columbia University Press. 1062 pp.

SÖDERSTRÖM, L., R. DE ROO \& T. HEDDERSON 2010. Taxonomic novelties resulting from recent reclassification of the Lophoziaceae/ Scapaniaceae clade. - Phytotaxa 3: 47-53. 